\title{
Pengaruh Kecepatan Spindle, Kedalaman Penyayatan, dan Variasi Campuran Cairan Pendingin Terhadap Keausan Pahat Insert Karbida pada Proses Pembubutan
}

\author{
Angga Suhendi ${ }^{1}$, Yoto $^{2}$, Marsono $^{3}$ \\ ${ }^{1,2,3}$ Program Studi S1 Pendidikan Teknik Mesin Jurusan Teknik Mesin \\ ${ }^{1,2,3}$ Fakultas Teknik Universitas Negeri Malang \\ 1,2,3 Jalan Semarang No. 5, Malang 65145 \\ Email: anggasuhendi22@gmail.com1
}

\begin{abstract}
Abstrak: Penelitian bertujuan untuk mengetahui pengaruh dari kombinasi variabel terhadap keausan pahat insert karbida. Variabel bebas yang digunakan yaitu kecepatan spindle (630 rev/min, $920 \mathrm{rev} / \mathrm{min}$, dan $1250 \mathrm{rev} / \mathrm{min})$, kedalaman penyayatan $(0.5 \mathrm{~mm}, 0.7 \mathrm{~mm}$, dan $1 \mathrm{~mm})$, dan campuran cairan pendingin $(1: 10,1: 25$, dan 1:40), serta variabel terikat berupa nilai keausan pahat insert karbida. Variabel kontrol berupa debit cairan pendingin ( $25 \mathrm{ml} / \mathrm{detik})$ dan Feeding $(0,08 \mathrm{~mm} / \mathrm{rev})$. Pahat yang digunakan adalah pahat merk Tungaloy dengan tipe WNMG080412-TSF T9125. Metode yang digunakan dalam penelitian adalah metode penelitian eksperimen dengan menerapkan desain Pre-Eksperimental studi kasus bentuk tunggal. Hasil dari penelitian menunjukkan bahwa semakin besar kecepatan spindle, kedalaman penyayatan dan semakin besar perbandingan cairan pendingin, maka semakin besar pula nilai keausan yang dihasilkan.
\end{abstract}

Kata kunci: kecepatan spindle, kedalaman penyayatan, campuran cairan pendingin, keausan pahat insert karbida.

\begin{abstract}
This study aims to determine the effect of combinations parameters had on the Wear of Carbide Insert Tool. Uses independent variables spindle speed of $630 \mathrm{rpm}, 920 \mathrm{rpm}$ and $1250 \mathrm{rpm}$, depth of cut of $0.5 \mathrm{~mm}, 0.7 \mathrm{~mm}$, and $1 \mathrm{~mm}$, and a mixture of coolant 1:10,1:25, and 1:40, and the dependent variable in this study is the Wear of Carbide Insert Tool. The control variable is the cooling liquid discharge $25 \mathrm{ml} / \mathrm{sec}$ and Feeding (f): $0.08 \mathrm{~mm} / \mathrm{rev}$. The tool used is the tungaloy Insert brand type WNMG080412-TSF T9125. This study used an experimental method with a pre-experimental study design of the one shot case study. The results showed that the greater the spindle speed, the depth of cut and the variation of the coolant mixture, the greater the value of the tool wear produced.
\end{abstract}

Keywords: Spindle speed, depth of cut, mixing of cooling liquids, Wear of Carbide Insert Tool

Pembuatan produk berkualitas tinggi tentunya harus didukung oleh proses pemesinan yang baik. Proses pemesinan adalah manufaktur yang memiliki proses utama menghilangkan sebagian material dari suatu bahan dasar yang dapat berupa blok sehingga memenuhi bentuk dan kuailitas yang didinginkan (Romiyadi \& Yudi, 2012). Selain kuantitas hasil produksi, kualitas dari hasil produksi memegang peranan penting dalam memperoleh kepercayaan konsumen. Proses pemesinan tidak lepas dari penggunaan alat potong atau pahat. Alat potong atau pahat merupakan komponen utama yang digunakan di dalam proses pemesinan, khususnya pada pembubutan (turning process). Alat potong adalah alat/pisau yang digunakan untuk menyayat benda kerja (Sumbodo, 2008:253). Terdapat beberapa jenis material pahat/alat potong, diantaranya: baja karbon, HSS (High Speed Steel), paduan cor nonferro, karbida, keramik, CBN (Cubic Boron Nitrides), dan intan (Nugroho, 2010).

Pemilihan jenis alat potong didasarkan pada jenis material benda kerja. Jika dibandingkan dengan pahat jenis karbida, pengasahan pahat HSS yang dilakukan secara manual tidak menjamin pahat tersebut memiliki kepresisian geometri sudut yang sama satu dengan yang lain. Berbeda dengan pahat insert karbida, pahat tersebut memiliki ketajaman dan ukuran sudut yang sudah sesuai dengan standar ukuran yang di rekomendasikan. Terdapat bagian penting dari pahat bubut yang sering mengalami kerusakan cukup signifikan. Bagian yang memiliki peran penting dalam menentukan baik tidaknya permukaan hasil pembubutan yaitu proses keausan pahatnya (Bayuseno, 2010). Keausan pahat yang terjadi akan semakin membesar sampai batas tertentu sehingga pahat tidak dapat dipergunakan lagi. Pahat yang mengalami keausan akan menimbulkan gaya pemotongan yang besar sehingga dapat menyebabkan kerusakan fatal. Untuk memperkecil kerusakan, maka penggunaan cairan pendingin pada proses pemotongan khususnya pembubutan sangat diperlukan.

\section{METODE}

Metode yang digunakan adalah metode eksperimen dengan menerapkan jenis desain Pre-Eksperimental studi kasus bentuk tunggal (one shot case study) dimana subjek disajikan dengan beberapa jenis perlakuan lalu diukur hasilnya. One shot case study yaitu sebuah eksperimen yang dilaksanakan tanpa adanya sekelompok pembanding dan juga tanpa tes awal (Arikunto, 2005:212) 


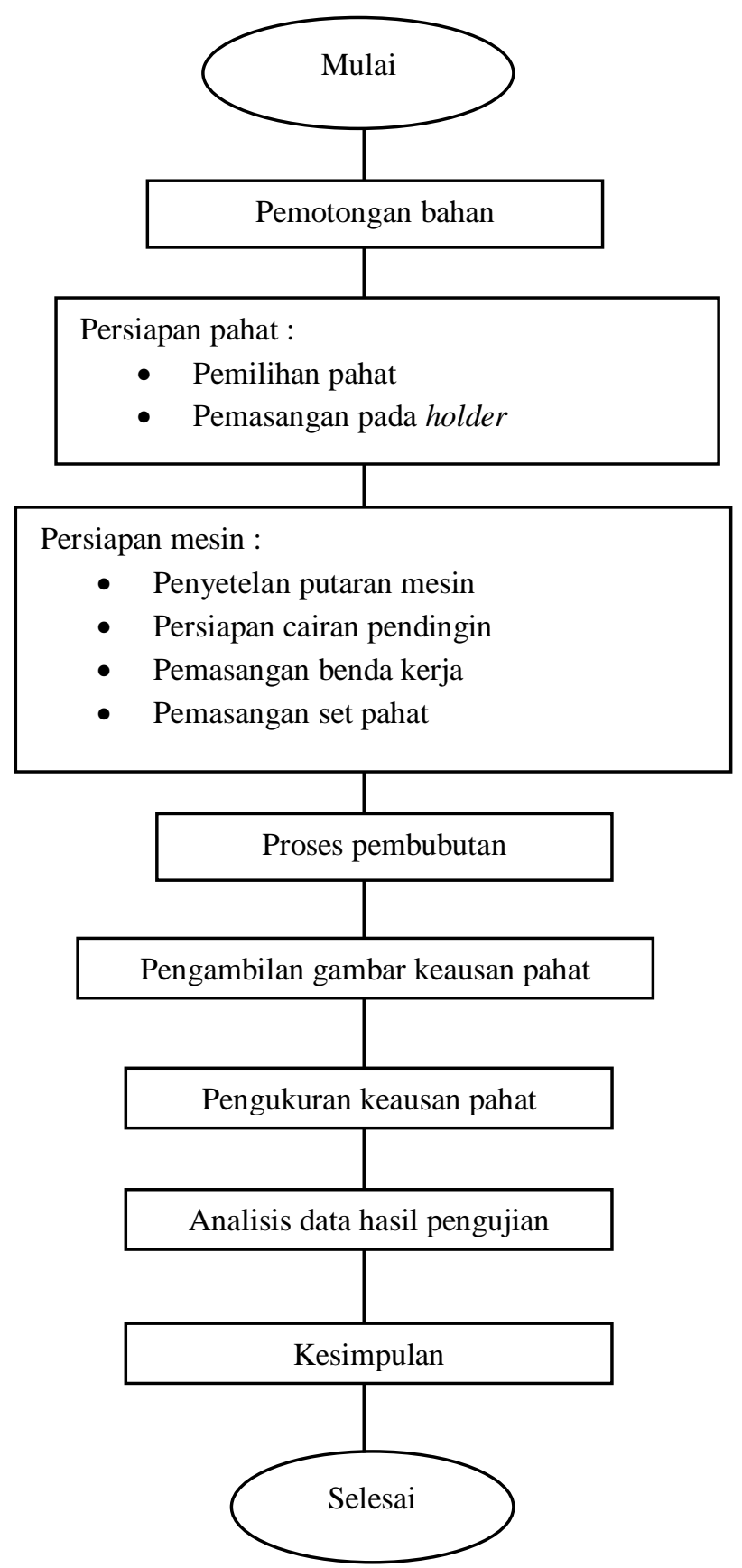

Gambar 1. Alur penelitian

Tabel I. Desain Penelitian

\begin{tabular}{ccccc}
\hline \multirow{2}{*}{$\begin{array}{c}\text { Kecepatan Spindle } \\
(\mathbf{r p m})\end{array}$} & $\begin{array}{c}\text { Kedalaman } \\
\text { Penyayatan }\end{array}$ & \multicolumn{4}{c}{ Nilai Keausan (mm) } \\
\cline { 3 - 5 }$(\mathbf{m m})$ & 0,5 & $1: 10$ & $1: 25$ & $1: 40$ \\
\cline { 3 - 5 } & \multirow{2}{*}{630} & $\mathrm{P} 1$ & $\mathrm{P} 2$ & $\mathrm{P} 3$ \\
\cline { 2 - 5 } & 1 & $\mathrm{P} 4$ & $\mathrm{P} 5$ & $\mathrm{P} 6$ \\
\cline { 2 - 5 } & & $\mathrm{P} 7$ & $\mathrm{P} 8$ & $\mathrm{P} 9$ \\
\hline
\end{tabular}




\begin{tabular}{|c|c|c|c|c|}
\hline \multirow{3}{*}{$\begin{array}{c}\text { Kecepatan Spindle } \\
(\mathbf{r p m})\end{array}$} & \multirow{3}{*}{$\begin{array}{c}\text { Kedalaman } \\
\text { Penyayatan } \\
(\mathbf{m m})\end{array}$} & \multicolumn{3}{|c|}{ Nilai Keausan (mm) } \\
\hline & & \multicolumn{3}{|c|}{ Variasi Campuran Cairan Pendigin } \\
\hline & & $1: 10$ & $1: 25$ & $1: 40$ \\
\hline \multirow{3}{*}{920} & 0,5 & P10 & $\mathrm{P} 11$ & $\mathrm{P} 12$ \\
\hline & 0,7 & P13 & P14 & $\mathrm{P} 15$ \\
\hline & 1 & $\mathrm{P} 16$ & $\mathrm{P} 17$ & $\mathrm{P} 18$ \\
\hline \multirow{3}{*}{1250} & 0,5 & P19 & $\mathrm{P} 20$ & $\mathrm{P} 21$ \\
\hline & 0,7 & $\mathrm{P} 22$ & $\mathrm{P} 23$ & $\mathrm{P} 24$ \\
\hline & 1 & $\mathrm{P} 25$ & P26 & P27 \\
\hline
\end{tabular}

Masing-masing dari variabel bebas tersebut memiliki tiga variasi. Variabel bebas yang digunakan yaitu Kecepatan spindle (630 rpm, $920 \mathrm{rpm}$, dan $1250 \mathrm{rpm})$, Kedalaman penyayatan $(0.5 \mathrm{~mm}, 0.7 \mathrm{~mm}$, dan $1 \mathrm{~mm})$, dan variasi campuran cairan pendingin $(1: 10,1: 25$, dan 1:40). Variabel kontrol yang digunakan yaitu debit cairan pendingin $25 \mathrm{ml} / \mathrm{detik}$, feeding (f) 0,08 $\mathrm{mm} / \mathrm{rev}$, panjang pencekaman $30 \mathrm{~mm}$, dan metode penyayatan memanjang dengan menggunakan tailstock.

Tempat penelitian di gedung G2 lantai satu yakni laboratorium mesin Universitas Negeri Malang. Waktu pelaksanaan peneli-tian ini yaitu pada tanggal 20 hingga 27 Mei 2019.

\section{HASIL}

Tabel II. Desain Hasil Penelitian

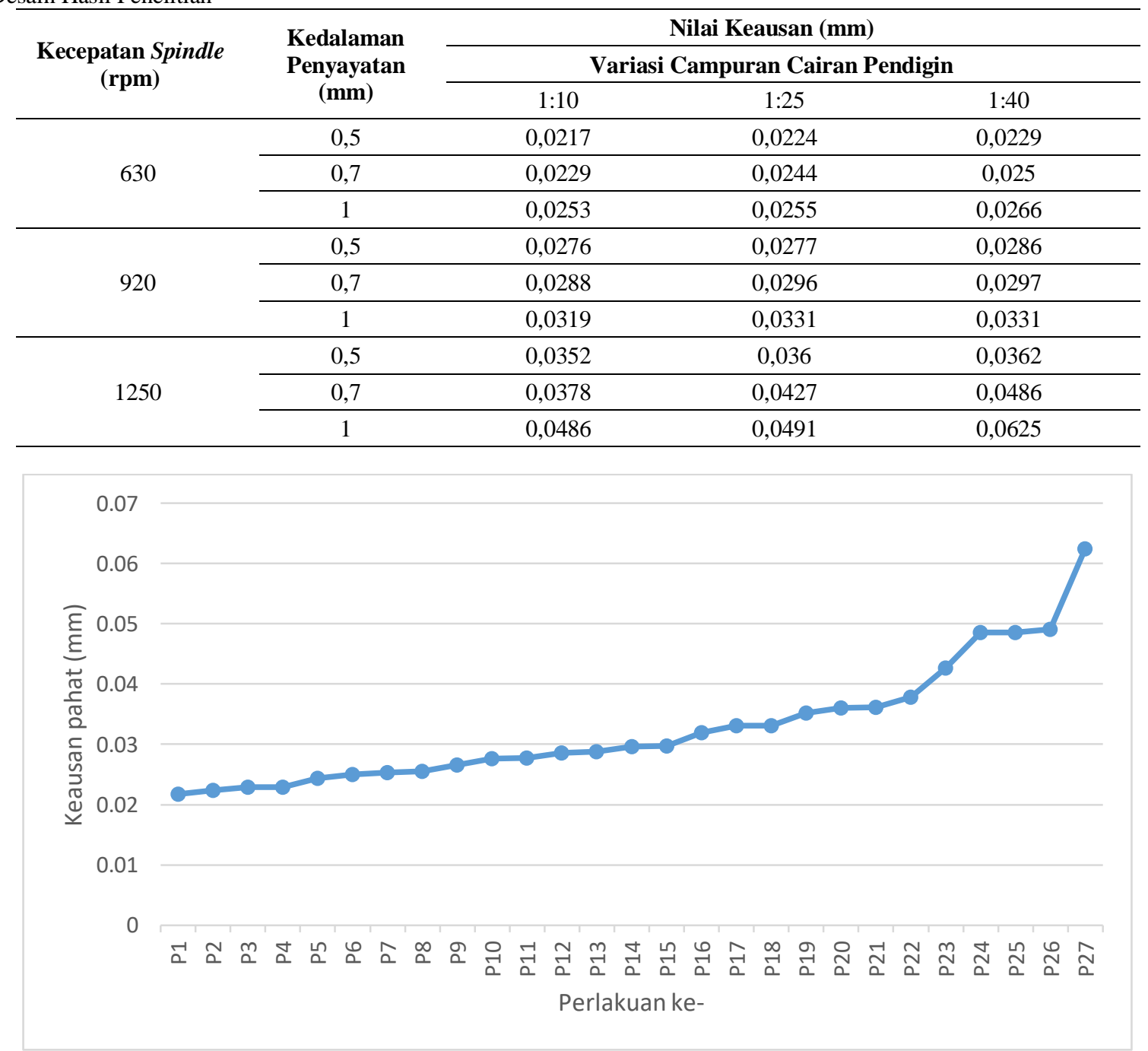

Gambar 2. Grafik keausan secara simultan 


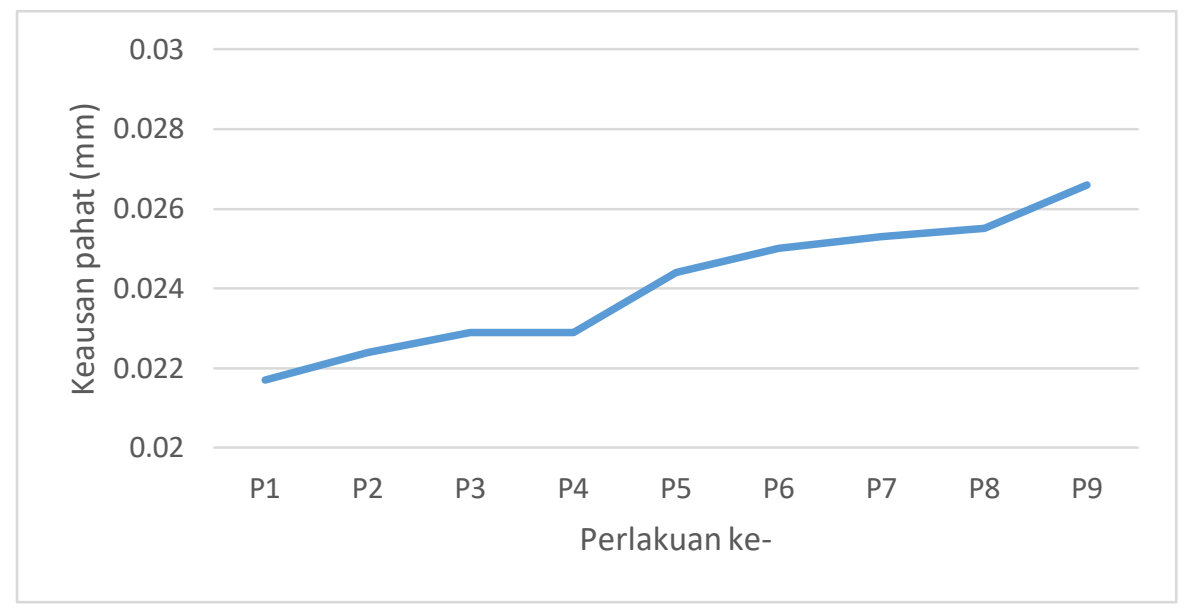

Gambar 3. Grafik keausan pada kecepatan spindle 630 rev/min

Pada kecepatan spindle sebesar $630 \mathrm{rev} / \mathrm{min}$ (Gambar 6), tingkat keausan pahat insert karbida terendah $(0,0217 \mathrm{~mm})$ terjadi pada proses perlakuan ke-1. Perlakuan ke-1 adalah proses pembubutan dengan menggunakan kedalaman penyayatan sebesar 0,5 $\mathrm{mm}$ dan perbandingan campuran cairan pendingin sebesar 1:10. Sedangkan tingkat keausan pahat insert karbida dengan nilai tertinggi $(0,0266 \mathrm{~mm})$ terjadi pada proses perlakuan ke-9. Perlakuan ke-9 adalah proses pembubutan dengan menggunakan kedalaman penyayatan sebesar $1 \mathrm{~mm}$ dan perbandingan campuran cairan pendingin sebesar 1:40.

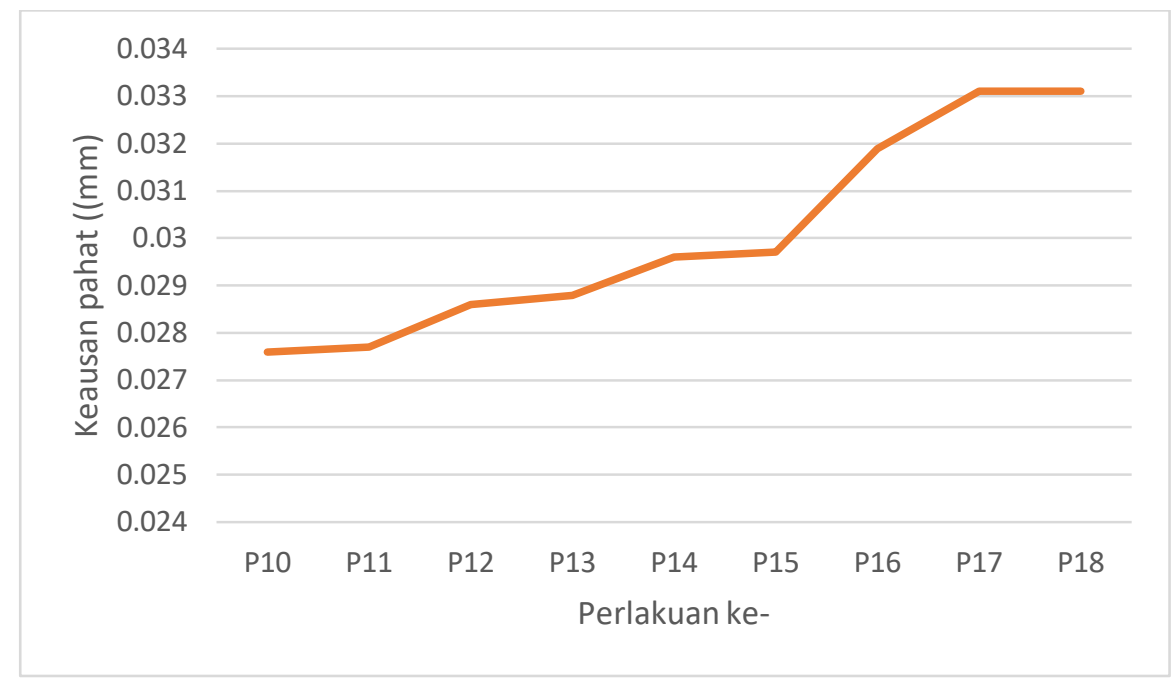

Gambar 4. Grafik keausan pada kecepatan spindle $920 \mathrm{rev} / \mathrm{min}$

Pada kecepatan spindle sebesar $920 \mathrm{rev} / \mathrm{min}$ (Gambar 7) tingkat keausan pahat insert karbida terendah $(0,0276 \mathrm{~mm})$ terjadi pada proses perlakuan ke-10. Perlakuan ke-10 adalah proses pembubutan dengan menggunakan kedalaman penyayatan sebesar 0,5 mm dan perbandingan campuran cairan pendingin sebesar 1:10. Sedangkan tingkat keausan pahat insert karbida dengan nilai tertinggi $(0,0331 \mathrm{~mm})$ terjadi pada proses perlakuan ke-18. Perlakuan ke-18 adalah proses pembubutan dengan menggunakan kedalaman penyayatan sebesar $1 \mathrm{~mm}$ dan perbandingan campuran cairan pendingin sebesar 1:40. 


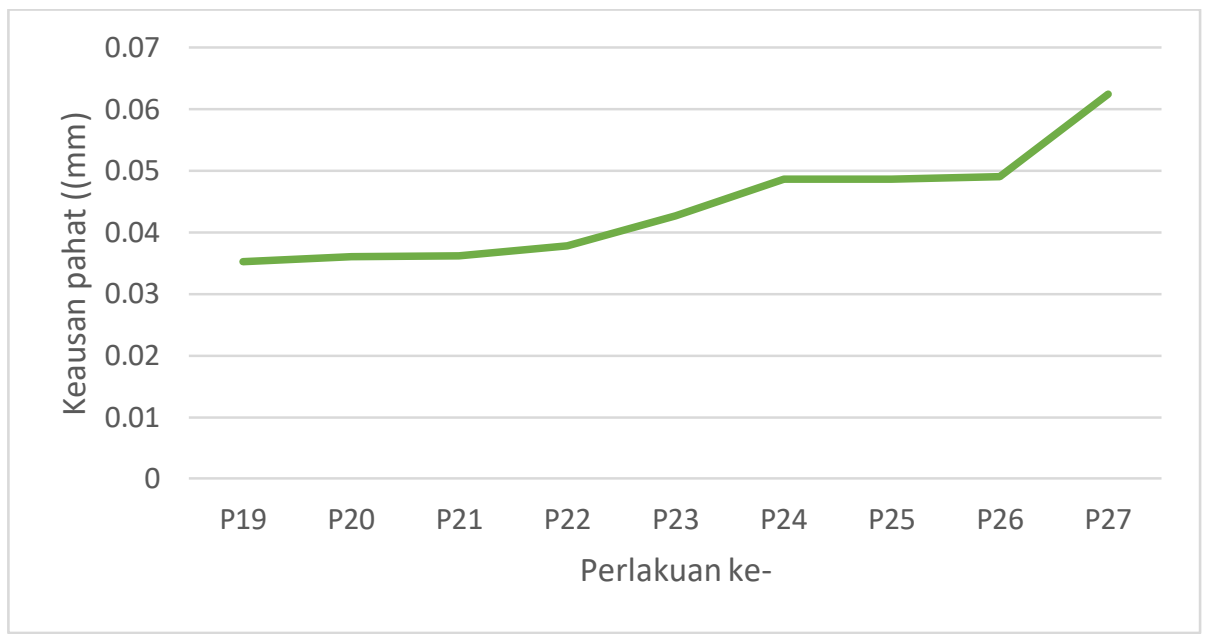

Gambar 5. Grafik keausan pada kecepatan spindle $1250 \mathrm{rev} / \mathrm{min}$

Pada kecepatan spindle sebesar $1250 \mathrm{rev} / \mathrm{min}$ (Gambar 8), hasil tingkat keausan pahat insert karbida terendah (0,0352 $\mathrm{mm}$ ) terjadi pada proses perlakuan ke-19. Perlakuan ke-19 merupakan proses pembubutan dengan menggunakan kedalaman penyayatan sebesar $0,5 \mathrm{~mm}$ dan perbandingan campuran cairan pendingin sebesar 1:10. Sedangkan tingkat keausan pahat insert karbida dengan nilai tertinggi $(0,0625 \mathrm{~mm})$ terjadi pada proses perlakuan ke-27. Perlakuan ke-27 adalah proses pembubutan dengan menggunakan kedalaman penyayatan sebesar $1 \mathrm{~mm}$ dan perbandingan campuran cairan pendingin sebesar 1:40.

Berdasarkan pada gambar 5, tingkat keausan paling rendah terjadi pada perlakuan ke-1 sebesar 0,0217 mm, dimana variasi penyayatan yang diterapkan meliputi penggunaan kecepatan putaran spindle sebesar $630 \mathrm{rev} / \mathrm{min}$, kedalaman penyayatan sebesar $0,5 \mathrm{~mm}$, dan dengan menggunakan variasi perbandingan campuran cairan pendingin 1:10. Tingkat keausan paling tinggi terjadi pada perlakuan ke-27 sebesar $0,0625 \mathrm{~mm}$, dimana variasi penyayatan yang dilakukan adalah dengan menggunakan kecepatan putaran spindle sebesar $1250 \mathrm{rev} / \mathrm{min}$, kedalaman penyayatan sebesar $1 \mathrm{~mm}$, dan dengan menggunakan variasi campuran cairan pendingin dengan perbandingan 1:40.

\section{PEMBAHASAN}

Berdasarkan hasil, tingkat keausan terendah di setiap kecepatan spindle diperoleh pada saat penyayatan menggunakan kedalaman penyayatan terendah dan dikombinasikan dengan penggunaaan tingkat campuran cairan pendingin terendah (kental). Pada kondisi penyayatan tersebut, pahat insert akan memiliki umur cenderung lebih lama. Disamping karena mengalami proses pendinginan yang optimal serta pelumasan yang baik, hal tersebut juga disebabkan pahat tidak mengalami beban penyayatan yang tinggi. Semakin kecil kedalaman penyayatan maka tebal beram yang dihasilkan akan semkain kecil, sehingga gaya pemotongan yang terjadi akan mengalami penurunan. Dengan menurunnya gaya pemotongan, secara otomatis kinerja pahat selama proses penyayatan akan semakin ringan. Sejalan dengan hal tersebut, Siswanto (2018) menyebutkan bahwa kedalaman penyayatan (depth of cut) yang paling kecil akan menghasilkan nilai kekasaran yang kecil pula (halus) dan membuat umur pahat reltif lebih lama. Pahat yang mengalami keausan/kegagalan akan memperbesar gaya pemotongan sehingga dapat menimbulkan kerusakan yang fatal. Dan untuk memperkecil kemungkinan agar hal tersebut tidak terjadi, maka penggunaan cairan pendingin pada proses pemotongan khususnya pembubutan sangat diperlukan.

Semakin besar nilai dari perbandingan cairan pendingin maka cairan pendingin akan semakin encer. Sebaliknya, bila semakin kecil nilai perbandingan cairan pendingin, maka cairan pendingin yang dihasilkan akan semakin kental. Jadi semakin banyak campuran minyak (dromus) dengan air akan semakin cepat mendinginkan dan akan mengurangi gaya gesek yang ditimbulkan antara benda kerja dan pahat (Asrori, 2016). Dengan meminimalkan gaya gesek yang terjadi, secara otomatis panas yang dihasilkan akibat gesekan akan semakin rendah. Santoso (2013:49) menyebutkan bahwa Keausan atau kegagalan pada pahat disebabkan oleh adanya keausan yang secara bertahap membesar pada bidang aktif pahat.

Peningkatan besar keausan sejalan dengan bertambah cepatnya putaran spindle (Gambar 5). Hasil penelitian ini menyebutkan bahwa tingkat keausan terendah terjadi pada saat penggunaan kecepatan spindle dengan putaran rendah dan tingkat keausan tertinggi terjadi pada saat penggunan kecepatan spindle dengan putaran tertinggi. Dengan semakin cepatnya putaran spindle, maka akan semakin sering pahat mengalami kontak langsung dengan benda kerja. kontak langsung inilah yang akan menimbulkan gesekan dan membuat suhu dari pahat akan mengalami peningkatan, serta dapat menyebabkan keausan pada pahat. Pada kondisi ini peran dari media pendingin diperlukan. Media pendingin merupakan cairan yang memiliki salah satu fungsi untuk mengurangi panas yang ditimbulkan akibat gesekan antara pahat dengan benda kerja.

Semakin besarnya kecepatan spindle, maka semakin besar pula nilai kecepatan potong. Oleh karena putaran yang tinggi, mengakibatkan sedikitnya waktu untuk melepas panas dan semakin meningkatkan panas pada pahat (Kalpakjian, 1985:487). Dengan kata lain, energi yang berada pada area tersebut semakin besar, menghasilkan panas lebih tinggi, dan 
meningkatkan keausan pada pahat (Astakhov, 2006:82). Penelitian yang dilakukan oleh Digda (2015) mengemukakan bahwa kecepatan putaran spindle berpengaruh signifikan terhadap keausan pahat karbida pada proses turning CNC. Sejalan dengan hasil penelitian yang dilakukan oleh Andika (2013), beliau menyatakan bahwa putaran spindle dan kedalaman pemotongan berpengaruh terhadap keausan pahat rhombic insert. Semakin besar putaran spindle yang digunakan maka semakin besar pula keausan pada pahatnya. Dengan kata lain semakin besar putaran spindle dalam proes penyayatan, maka semakin sering pahat mengalami gesekan dengan benda kerja. Gesekan inilah yang menghasilkan temperatur yang tinggi pahatnya. Tingginya temperatur yang dihasilkan dapat memicu deformasi plastis pada material pahat yang mengakibatkan pelepasan ikatan antar partikel penyusun pahat secara terus menerus.

\section{Simpulan}

\section{SIMPULAN DAN SARAN}

Dari hasil penelitian dapat diambil kesimpulan bahwa (1) Kecepatan putaran spindle $630 \mathrm{rev} / \mathrm{min}$ dan kedalaman penyayatan $(0.5 \mathrm{~mm}, 0.7 \mathrm{~mm}$, dan $1 \mathrm{~mm})$ dengan variasi campuran cairan pendingin $(1: 10,1: 25$, dan 1:40) berpengaruh terhadap keausan pahat insert karbida pada proses pembubutan. Semakin besar kedalaman penyayatan dan semakin besar perbandingan cairan pendingin, maka semakin besar pula nilai keausan yang dihasilkan. (2) Kecepatan putaran spindle 920 rev/min dan kedalaman penyayatan $(0.5 \mathrm{~mm}, 0.7 \mathrm{~mm}$, dan $1 \mathrm{~mm})$ dengan variasi campuran cairan pendingin $(1: 10,1: 25$, dan 1:40) berpengaruh terhadap keausan pahat insert karbida pada proses pembubutan. Semakin besar kedalaman penyayatan dan semakin besar perbandingan cairan pendingin, maka semakin besar pula nilai keausan yang dihasilkan. (3) Kecepatan putaran spindle $1250 \mathrm{rev} / \mathrm{min}$ dan kedalaman penyayatan $(0.5 \mathrm{~mm}, 0.7 \mathrm{~mm}$, dan $1 \mathrm{~mm})$ dengan variasi campuran cairan pendingin $(1: 10,1: 25$, dan 1:40) berpengaruh terhadap keausan pahat insert karbida pada proses pembubutan. Semakin besar kedalaman penyayatan dan semakin besar perbandingan cairan pendingin, maka semakin besar pula nilai keausan yang dihasilkan, dan (4) Kecepatan putaran spindle $(630 \mathrm{rev} / \mathrm{min}, 920 \mathrm{rev} / \mathrm{min}$, dan $1250 \mathrm{rev} / \mathrm{min})$ dan kedalaman penyayatan $(0.5 \mathrm{~mm}, 0.7 \mathrm{~mm}$, dan 1 $\mathrm{mm})$ dengan variasi campuran cairan pendingin $(1: 10,1: 25$, dan 1:40) berpengaruh terhadap keausan pahat insert karbida pada proses pembubutan. Semakin besar kecepatan spindle, kedalaman penyayatan dan semakin besar perbandingan cairan pendingin, maka semakin besar pula nilai keausan yang dihasilkan.

\section{Saran}

Beberapa saran yang ditujukan untuk peneliti lebih lanjut antara lain (1) Pemilihan pahat berkaitan dengan keefektifan pekerjaan dimana harus disesuaikan dengan jenis bahan dari benda kerja. Pemilihan parameter pemotongan yang baik dan benar dapat mempengaruhi kualitas benda kerja, biaya operasional, dan produktivitas kerja pada pekerjaan menggunakan mesin bubut. (2) Ketika dilakukan penelitian lebih lanjut mengenai pengaruh kecepatan putaran spindle, kedalaman penyayatan, dan variasi campuran cairan pendingin terhadap keausan pahat insert karbida, saran bagi peneliti selanjutnya adalah agar menggunakan nilai variabel kecepatan spindle yang lebih tinggi untuk melihat respon apakah nilai keausan pahat yang dihasilkan akan semakin rendah atau semakin tinggi. Kemudian tetap gunakan parameter cairan pendingin untuk sedikit banyak meminimalisir resiko dari kerusakan bahan, pahat, dan kecelakaan kerja. Selanjutnya, untuk dapat memaksimalkan hasil penelitian yang lebih baik, sebaiknya mengunakan mesin bubut CNC untuk meminimalisir terjadinya vibrasi dan keterbatasan besaran parameter pembubutan yang terdapat pada mesin bubut manual.

\section{DAFTAR RUJUKAN}

Andika, R. 2013. Pengaruh Putaran Spindle dan Depth Of Cut Terhadap Keausan Pahat Positive Rhombic Insert Pada Proses Turning. Fakultas Teknik, Universitas Brawijaya.

Astakhov, V.P. (Eds.). 2006. Tribology of Metal Cutting. Elsevier.

Arikunto, S. 2013. Prosedur Penelitian, Suatu Pendekatan Praktik. Jakarta: Rineka Cipta.

Digda, Y. 2015. Pengaruh Putaran Spindle dan Kecepatan Pemotongan (Feeding) Terhadap Keausan Pahat Karbida Pada Proses Turning CNC. Skripsi tidak diterbitkan. Malang: Universitas Negeri Malang.

Kalpakjian, S. 1985. Manufacturing Processes For Engineering Materials. Canada: Addison-Wesley Publishing.

Nugroho, S. 2010. Karakterisasi Pahat Bubut High Speed Steel (HSS) Boehler Tipe Molibdemum (M2) Dan Tipe Cold Work Tool Steel (A8). Skripsi tidak diterbitkan. Jember : Universitas Negeri Jember.

Rochim, T., 2007,” Klasifikasi Proses, Gaya dan Daya Pemesinan”, ITB. Bandung.

Romiyadi. \& Yudi, D. 2012. Pengaruh Parameter Kecepatan Putaran Spindel Terhadap Getaran Mesin Perkakas Pada Proses Up Milling Dan Down Cut Milling Menggunakan Mesin Frais Universal KNUTH UFM 2. Jurnal Sawit Indonesia, Vol. 2 No. 2.

Santoso, J. 2013. Pekerjaan Mesin Perkakas. Jakarta: Direktorat Peningkatan Mutu Pendidik \& Tenaga Kependidikan Kementerian Pendidikan dan Kebudayaan.

Siswanto, B. 2018. Pengaruh Kecepatan Dan Kedalaman Potong Pada Proses Pembubutan Konvensional Terhadap Kekasaran Permukaan Lubang, (online), (http://jurnalmahasiswa.unesa.ac.id/), diakses 2 Juli 2019

Sugiyono. 2011. Statistika Untuk Penelitian. Bandung: Alfabeta. 
140 Angga Suhendi, Yoto, Marsono - Pengaruh Kecepatan Spindle, Kedalaman Penyayatan, dan Variasi Campuran .....

Sumbodo, W. 2008. Teknik Produksi Mesin Industri Jilid 2. Jakarta: Direktorat Jenderal Manajemen Pendidikan Dasar dan Menengah Departemen Pendidikan Nasional.

,(online).https://www.google.com/search?q=geometri+pahat\&client=firefoxb\&source=lnms\&tbm=isch\&sa=X\&ved=0ahU KEwiLsIiBmqfUAhUJRY8KHf_xDU8Q_AUICigB\&biw=1366\&bih=659\#imgrc=JJCyQ2WlQjiwTM:. Diakses pada 15 Mei 2019. 